\title{
Flora do Espírito Santo: Phyllanthus (Phyllanthaceae)
}

\author{
Flora of Espírito Santo: Phyllanthus (Phyllanthaceae)
}

Erika Ramos Martins ${ }^{1,4}$, Letícia Ribes de Lima $^{2}$ \& Inês Cordeiro ${ }^{3}$

\begin{abstract}
Resumo
Phyllanthus, com cerca de 1.270 espécies, é pantropical, mas também ocorre em regiões temperadas de todo o planeta. No Brasil são registradas cerca de 100 espécies, que ocorrem em florestas, cerrados, campos e nas caatingas. O objetivo do presente trabalho foi estudar a taxonomia das espécies do gênero ocorrentes no estado do Espírito Santo. Para cada uma delas é indicada a coleções tipo, descrição, ilustração, chave de identificação, distribuição geográfica, período de floração e frutificação, além de comentários sobre caracteres morfológicos diagnósticos.
\end{abstract}

Palavras-chave: Euphorbiaceae s.l., Euphorbiaceae s.s., florística, taxonomia.

\begin{abstract}
Phyllanthus, with 1,270 species, is pantropical, but also occurs in temperate regions of the world. Around 100 species are recorded to Brazil and they can be found in forests, cerrados, grasslands and caatingas. This work aims to study perform a taxonomic survey the species of Phyllanthus from Espírito Santo state. Protologues, type collections, descriptions, illustrations, identification key, geographic distribution, phenology information, and taxonomic comments are provided.
\end{abstract}

Key words: Euphorbiaceae s.l., Euphorbiaceae s.s., floristics, taxonomy.

\section{Introdução}

A família Phyllanthaceae foi restabelecida por Chase et al. (2002), com base em estudos filogenéticos moleculares, já em parte previamente divulgados em seu trabalho anterior (Chase et al. 1993). Ela inclui 55 gêneros e 1745 espécies dispersas por todo o globo, principalmente nas regiões tropicais caracterizadas por flores unissexuadas, com ovário geralmente 3-carpelar com lóculos biovulados e estiletes bífidos, além de frutos esquizocárpicos e sementes geralmente sem carúnculas (Judd 2009).

Wurdack et al. (2004) e Hoffmann et al. (2006) reconheceram para ela duas subfamílias: Phyllanthoideae e Antidesmatoideae. A subfamília Phyllanthoideae caracteriza-se por apresentar epiderme desprovida de células taníferas, inflorescências glomeruliformes, flores com ou sem pétalas e cápsulas de deiscência explosiva, raramente bagas ou drupas, que no Brasil está representada pelos gêneros Phyllanthus L., Amanoa Aubl., Savia Willd., Discocarpus Klotzsch, Gonatogyne Klotzsch ex Müll. Arg., Meineckia Baill., Flueggea Willd. e Astrocasia B.L. Rob. \& Millsp. E a subfamília Antidesmatoideae, caracteriza-se pela presença de células taníferas na epiderme, inflorescências espiciformes, flores geralmente sem pétalas, e drupas não explosivos, representada no Brasil pelos gêneros Hieronyma Allemão e Richeria Vahl.

Phyllanthus é o maior e mais diversificado gênero de Phyllanthaceae com aproximadamente 1.270 espécies (Katrichchia et al. 2006), neste estudo, os gêneros Breynia J.R. Forst. \& G. Forst., Glochidion J.R. Forst. \& G. Forst., Reverchonia A. Gray e Sauropus Blume emergiram em meio

\footnotetext{
${ }^{1}$ Universidade Paulista - UNIP, Prog. Pós-graduação em Patologia Ambiental, R. Dr. Bacelar 1212,- Vila Clementino, 04026-002, São Paulo, SP, Brasil.

${ }^{2}$ Universidade Federal de Alagoas, Inst. Ciências Biológicas e da Saúde, Av. Lourival Melo Mota, s/n, Tabuleiro do Martins, 57072-970, Maceió, AL, Brasil.

${ }^{3}$ Secretaria do Meio Ambiente, Núcleo de Curadoria do Herbário de São Paulo, Inst. Botânica, Av. Miguel Stéfano, 3687, Água Funda, 04301-902, São Paulo, SP, Brasil.

${ }^{4}$ Autor para correspondência: eramosmartins@gmail.com
} 
a Phyllanthus, resultando em uma circunscrição mais ampla de Phyllanthus. Entretanto, ainda não foram publicadas alterações nomenclaturais para compatibilizar com esta proposta de recircunscrição. As espécies de Phyllanthus ocorrem em todas as regiões do planeta, sendo 200 delas nas Américas, 100 na África e 70 em Madagascar. As demais se distribuem pela Ásia e Austrália (Radcliffe-Smith 2001).

No Brasil, o último levantamento realizado por Webster (2002b) apontou a ocorrência de 107 espécies de Phyllanthus, e 99 de acordo com a Lista de Espécies da Flora do Brasil (BFG 2015), Todos os outros trabalhos sobre o gênero são descrições de novas espécies ou inventários de estados ou localidades mais restritas, que incluem descrições e ilustrações das espécies de Phyllanthus, bem como comentários sobre distribuição geográfica, dados fenológicos e aspectos taxonômicos (Tab. 1).

Este estudo objetivou realizar o levantamento das espécies de Phyllanthus ocorrentes no estado do Espírito Santo.

Tabela 1 - Principais trabalhos sobre o gênero Phyllanthus no Brasil.

Table 1 - Main works on the genus Phyllanthus in Brazil.

\begin{tabular}{|c|c|c|c|c|}
\hline Autor (ES) & Ano & Obra & Região estudada & № de espécies \\
\hline Müller, J.A. & 1873 & Flora brasiliensis & Brasil & 71 \\
\hline $\begin{array}{l}\text { Smith, L.B., Downs, R.J. } \\
\text { \& Klein R.M. }\end{array}$ & 1988 & Flora da Santa Catarina & Santa Catarina & 12 \\
\hline Cordeiro, I. & 1992 & $\begin{array}{l}\text { Flora da Serra do Cipó, Minas Gerais: } \\
\text { Euphorbiaceae }\end{array}$ & Minas Gerais & 7 \\
\hline $\begin{array}{l}\text { Torres, D.S.C., Cordeiro, I. } \\
\text { \& Giulietti, A.M. }\end{array}$ & 2003 & $\begin{array}{l}\text { O gênero Phyllanthus L. (Euphorbiaceae) } \\
\text { na Chapada Diamantina, Bahia, Brasil }\end{array}$ & Bahia & 11 \\
\hline Cordeiro, I. & 2004 & Flora de Grão Mogol, Minas Gerais & Minas Gerais & 5 \\
\hline Silva, M.J. \& Sales, M.F. & 2007 & $\begin{array}{l}\text { Phyllanthus L. (Phyllanthaceae) } \\
\text { em Pernambuco }\end{array}$ & Pernambuco & 17 \\
\hline Silva, M.J. \& Sales, M.F. & 2008 & $\begin{array}{l}\text { Sinopse do gênero Phyllanthus } \\
\text { (Phyllanthaceae) no Nordeste do Brasil }\end{array}$ & Região Nordeste & 36 \\
\hline $\begin{array}{l}\text { Secco, R.S., Cordeiro, I. } \\
\& \text { Martins, E.R. }\end{array}$ & 2010 & $\begin{array}{l}\text { Catálogo de plantas e fungos do Brasil } \\
\text { (Phyllanthaceae) }\end{array}$ & Brasil & 91 \\
\hline Martins, E.R. \& Lima, L.R. & 2011 & $\begin{array}{l}\text { Sinopse do gênero Phyllanthus } \\
\text { do estado de São Paulo }\end{array}$ & São Paulo & 16 \\
\hline Martins, E.R. \& Lima, L.R. & 2012 & Flora do estado de São Paulo & São Paulo & 15 \\
\hline $\begin{array}{l}\text { Martins, E.R., Lima, L.R. } \\
\text { \& Cordeiro, I. }\end{array}$ & 2014 & $\begin{array}{l}\text { Phyllanthus (Phyllanthaceae) } \\
\text { no estado do Rio de Janeiro }\end{array}$ & Rio de Janeiro & 20 \\
\hline
\end{tabular}

\section{Material e Métodos}

As coleções de Phyllanthus depositadas nos principais herbários do estado do Espírito Santo (CVRD, MBML e VIES) foram analisadas, além de coleções depositadas em outros herbários nacionais (EC, MBM, RB, SP e SPF) (acrônimos de acordo com Thiers, continuamente atualizado). Além disso, populações de algumas das espécies foram observadas no campo. Os comentários sobre a distribuição geográfica e habitats preferenciais das espécies foram baseados nas informações contidas nas etiquetas das exsicatas, nas observações feitas em campo e também em dados levantados de literatura específica, como os trabalhos do Webster $(1956,1957,1959,1967,1970,2011,2002 a, 2002 b$ e 2003) e os citados na Tabela 1.

As ilustrações foram elaboradas sob estereomicroscópio acoplado à câmara clara e 
constam de detalhes de flores, frutos e sementes, os quais são diagnósticos para identificação dos táxons.

No item "Material examinado", uma única coleção para cada espécie é apresentada (vide lista de exsicatas para a totalidade de material examinado). Quando o número de coletor for ausente, acrônimo e o número de registro da coleção botânica são citados.

\section{Resultados e Discussão}

Todas as 17 espécies de Phyllanthus encontradas no Espírito Santo são monoicas. Apenas Phyllanthus acuminatus e P. cladotrichus, possuem hábito arbustivo ou arbóreo, enquanto todas as outras são ervas ou subarbustos. Os ramos são cilíndricos ou achatados, com ou sem ramificação filantóide, pinatiformes ou bipinatiformes, algumas espécies apresentam os ramos modificados em cladódios como $P$. gladiatus e P. klotzschianus. As folhas possuem limbo desenvolvido na maioria das espécies, exceto no eixo principal das espécies com ramificação filantóide, como $P$. niruri, e naquelas com cladódios, onde são reduzidas a escamas, como P. klotzschianus, são geralmente dísticas, mas também podem ser espiraladas, como em $P$. pinifolius. As inflorescências são unissexuais ou bissexuais, cimosas, com flores solitárias ou até seis flores como em $P$. acuminatus. As flores possuem cinco a seis sépalas, de coloração esbranquiçada, amarelada ou esverdeada, mais raramente avermelhadas ou vináceas, como em alguns exemplares de $P$. orbiculatus e cladotrichus. $\mathrm{O}$ androceu formado por dois estames em $P$. cladotrichus e $P$. piranii, cinco (seis) em $P$. tenellus e três nas demais espécies. As flores masculinas possuem disco nectarífero geralmente comumente segmentado, exceto P. cladotrichus, em que é inteiro, ao passo que o disco feminino é usualmente inteiro, exceto em $P$. orbiculatus onde é segmentado. As cápsulas são geralmente lisas, mas podem ser ornamentadas como em $P$. urinaria. As sementes são trígonas com testa lisa, estriada ou verruculosa.

\section{Tratamento taxonômico}

\section{Phyllanthus L., Sp. Pl. 2: 981. 1753}

Ervas, subarbustos, raramente arbustos ou arvoretas, monóicos ou mais raramente dióicos; indumento, quando presente, de tricomas simples; ramificação frequentemente filantoide, onde folhas com limbo desenvolvido ocorrem apenas nos ramos plagiotrópicos, que podem ser pinatiformes (não ramificados) ou bipinatiformes (ramificados), cilíndricos, levemente achatados ou modificados em cladódios, há também o padrão não filantoide de ramificação onde as folhas desenvolvidas ocorrem em todos os ramos. Folhas alternas, geralmente dísticas ou espiraladas, simples, inteiras, pecioladas, estipuladas, escamiformes no eixo principal nas espécies com ramificação filantoide. Címulas axilares uni ou bissexuais; Flores masculinas com 5-6 sépalas, esverdeadas, rosadas ou vináceas; disco segmentado com 5-6 glândulas ou inteiro; estames (2-)3-5(-6) livres ou unidos, anteras 2-tecas, com deiscência horizontal ou vertical. Flores femininas com 5-6 sépalas semelhantes as masculinas em coloração; disco inteiro, raramente segmentado; gineceu 3-carpelar; lóculos biovulados; estiletes 3, livres ou unidos na base, geralmente 2-fidos. Cápsula septicida-loculicida, raramente baga ou drupa, liso ou ornamentado. Sementes 2 por lóculo, trígonas ou plano-convexas, lisas ou verrucosas, testa crustácea, castanha, não carúnculadas.

\section{Chave de identificação das espécies de Phyllanthus no Espírito Santo, Brasil}

1. Ramificação filantóide

2. Ramos modificados em cladódios

3. Arvoreta ombrófila do interior da mata, cladódios 30-40 cm compr., 2-4 cm larg. flores masculinas pediceladas 7. Phyllanthus gladiatus

3'. Subarbusto heliófilo da restinga, cladódios até $10 \mathrm{~cm}$ compr., 4-8 mm larg., flores masculinas sésseis 9. Phyllanthus klotzschianus

2'. Ramos não modificados em cladódios

4. Flores com seis sépalas

5. Estames livres 11. Phyllanthus orbiculatus

5'. Estames totalmente unidos pelos filetes 
6'. Ervas até $0,5 \mathrm{~m}$ alt., ramos pinatiformes...

17. Phyllanthus urinaria

4'. Flores com cinco sépalas

7. Estames totalmente unidos pelos filetes.

14. Phyllanthus stipulatus

7'. Estames livres. 8

8. Estames 5(-6)

8'. Estames 3

16. Phyllanthus tenellus

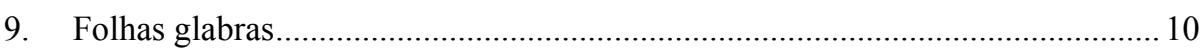

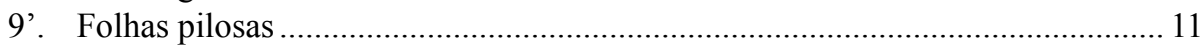

10. Pedicelo da flor feminina ca. $5 \mathrm{~mm}$, estiletes menores que as sépalas (ca. 0,5 mm compr.)

10. Phyllanthus niruri

10'. Pedicelo da flor feminina ca. $20 \mathrm{~mm}$, estiletes maiores que as sépalas (ca. 2,5 mm compr.)

3. Phyllanthus augustini

11. Folhas membranáceas, ovais, pedicelo da flor feminina 3-4 mm.

2. Phyllanthus arenicola

11'. Folhas subcartáceas, orbiculares a elípticas, pedicelo da flor feminina $1,5-2 \mathrm{~mm}$

4. Phyllanthus caparaoensis

1'. Ramificação não filantóide

12. Flores com 5 sépalas

13. Estames 2

13. Phyllanthus piranii

13'. Estames 3 14

14. Folhas orbiculares, glabras; pedicelo das flores femininas $3-5(-6) \mathrm{mm}$.

15. Phyllanthus subemarginatus

14'. Folhas ovais, pubescentes na face abaxial, pedicelo das flores femininas $11-12 \mathrm{~mm} . .$.

8. Phyllanthus hypoleucus

12'. Flores com seis sépalas

15. Ervas, estames livres

5. Phyllanthus caroliniensis

15'. Subarbustos a arvoretas, estames completamente unidos pelos filetes 16

16. Folhas espiraladas, lineares, coriáceas, $4-12 \times 1 \mathrm{~mm}$.

12. Phyllanthus pinifolius

16'. Folhas dísticas, largamente elíticas, membranáceas, 4-12 × 1,5-6 cm .

6. Phyllanthus cladotrichus

1. Phyllanthus acuminatus Vahl, Symbolae Botanicae 2: 95. 1791.

Tipo: TRINIDADE E TOBAGO, 1778, J. Ryan s.n. (holótipo BM n.v., fotografia do holótipo em BM! (BM000947320)).

Iconografia: Martins, Lima \& Cordeiro 2014: Figura 1a-b.

Arvoretas monóicas, 1,5-9 m alt., ramificação filantóide, ramos plagiotrópicos bipinatiformes; caule liso, ramos cilíndricos, pubescentes. Folhas membranáceas, levemente discolores, 14-35 × 5-20 mm, ovais; ápice agudo ou acuminado, às vezes apiculado; base retusa ou arredondada; face adaxial pubescente, face abaxial glabra ou pubescente; margem plana; nervação broquidódroma; pecíolos 1,5-3 mm compr.; estípulas ca. $1 \mathrm{~mm}$ compr., estreitamente triangulares, pubescentes. Címulas axilares compostas com 6 flores, às vezes, flores solitárias; brácteas ca. $1 \mathrm{~mm}$ compr., lanceoladas. Flores masculinas sépalas 6 ca. 0,5 mm compr., elípticas, membranáceas; alvo-esverdeadas; estames 3 , filetes completamente unidos formando uma coluna; anteras com deiscência horizontal; disco 3-lobado; pedicelo ca. $2 \mathrm{~mm}$ compr. Flores femininas sépalas $6,1 \mathrm{~mm}$ compr., elípticas; membranáceas; alvo-esverdeadas; ovário $0,5 \mathrm{~mm}$ compr., estiletes 3, 2-fidos; disco inteiro; pedicelo $10-11 \mathrm{~mm}$ compr. Cápsulas $4 \times 2-4 \mathrm{~mm}$. Sementes 2-2,5 mm compr., avermelhadas, lisas.

Material examinado: Colatina, III.1934, fl. e fr., J.G. Kuhlmann 34 (RB).

Phyllanthus acuminatus pode ser confundido com P. cladotrichus, pois ambos são arvoretas, possuem flores com seis sépalas e três estames com filetes unidos. Porém, P. acuminatus possui ramos bipinatiformes e folhas ovais com ápice agudo ou acuminado, às vezes apiculado, com base retusa ou arredondada, e geralmente ocorre em florestas estacionais. Já P. cladotrichus 
possui ramos pinatiformes e folhas elípticas, com ápice cuspidado ou acuminado, base aguda ou arredondada e ocorre no interior de floresta ombrófila.

Espécie exclusiva das Américas, ocorrendo desde o norte do México até o norte da Argentina, incluindo Antilhas (Webster 2003; Silva \& Sales 2007). No Brasil é registrado para as regiões Norte, Nordeste, Centro-Oeste e Sudeste, geralmente em floresta estacional semidecidual (BFG 2015).

Coletada com flores e frutos nos meses de março e maio e de outubro a dezembro.

2. Phyllanthus arenicola Casar. Novarum Stirpium Brasiliensium Decades 10, p. 88. 1845. Tipo: BRASIL. RIO DE JANEIRO: Taipú. 183940, G. Casaretto 1793 (holótipo G n.v., referido por Webster (2002a)).

Iconografia: Martins, Lima \& Cordeiro 2014: Figura $1 \mathrm{c}-\mathrm{d}$.

Ervas monóicas, $0,3-1 \mathrm{~m}$ alt.; ramificação filantóide, ramos plagiotrópicos pinatiformes, caule liso, ramos cilíndricos, pubescentes. Folhas membranáceas, discolores, 5-9 $\times$ 3-6 mm; ovais; ápice acuminado ou agudo; base aguda ou arredondada; faces adaxial e abaxial pubescentes; margem levemente revoluta; nervação broquidódroma; pecíolos 1-1,5 mm compr.; estípulas 1,5-2 mm compr., elípticas ou triangulares, glabras. Címulas axilares, compostas por 2-3 flores ou, às vezes, flores solitárias; brácteas ca. $1 \mathrm{~mm}$ compr., estreitamente triangulares. Flores masculinas sépalas 5,1-1,5 mm compr., elípticas ou obovais, membranáceas; alvo-esverdeadas; estames 3, filetes livres; anteras com deiscência horizontal; disco 5-lobado; pedicelo 2,5-3 mm compr. Flores femininas sépalas $5,1-1,5 \mathrm{~mm}$ compr., elípticas ou obovais; alvo-esverdeadas; ovário $0,5 \mathrm{~mm}$ compr., estiletes 3, 2-fidos até a metade; disco inteiro; pedicelo 3-4 $\mathrm{mm}$ compr. Cápsulas ca. 3 $\times 2 \mathrm{~mm}$. Sementes 1-1,5 mm compr., castanhoamareladas, verruculosas.

Material examinado: Santa Maria de Jetibá, I.2003, fl., L. Kollmann et al. 5970 (MBML).

Phyllanthus arenicola, assim como $P$. piranii, possui indumento nos ramos e folhas; entretanto estas espécies podem ser diferenciadas pelo tamanho das folhas $(5-9 \times 3-6 \mathrm{~mm}$ compr. na primeira e $8-15 \times 7-13 \mathrm{~mm}$ compr. na segunda), e androceu, que em $P$. arenicola possui três estames e em $P$. piranii apenas dois.
Trata-se de um táxon endêmico do Brasil com distribuição conhecida até então para a região Sudeste onde cresce em restingas e na transição destas com floresta ombrófila densa atlântica de encosta e os campos de altitude (BFG 2015).

Coletada com flores nos meses de janeiro, fevereiro, março e julho e frutos apenas em julho.

3. Phyllanthus augustinii Baill., Adansonia 5: 354. 1865.

Tipo: BRASIL. RIO DE JANEIRO: 1816-1821, A. Saint-Hilaire 743 (holótipo P n.v., fotografia do holótipo em P!).

Iconografia: : Martins, Lima \& Cordeiro 2014: Figura 1 e-f.

Ervas monóicas, 0,4 $\mathrm{m}$ alt.; ramificação filantóide, ramos plagiotrópicos pinatiformes; caule liso, ramos cilíndricos, pubescentes. Folhas membranáceas, discolores, 5-10 × 3-5 mm; oblongas; ápice arredondado, às vezes apiculado; base arredondada, assimétrica; faces adaxial e abaxial glabras; margem revoluta; nervação broquidódroma; pecíolos ca. $1 \mathrm{~mm}$ compr., glabros; estípulas ca. $2 \mathrm{~mm}$ compr., triangulares, glabras. Címulas axilares resumidas a uma única flor; brácteas ca. $1 \mathrm{~mm}$ compr., triangulares. Flores masculinas sépalas 5, 1-1,5 mm compr., obovais, membranáceas; alvo-esverdeadas; estames 3, filetes livres; anteras com deiscência horizontal; disco 5-lobado; pedicelo 5-6 $\mathrm{mm}$ compr. Flores femininas sépalas 5, 1,5-2 mm compr., obovais; alvo-esverdeadas; ovário ca. 1 mm compr., estiletes 3, 2-fidos a partir da metade; disco 5-lobado; pedicelo ca. $22 \mathrm{~mm}$ compr. Cápsulas e sementes não observadas.

Material examinado: Santa Teresa, IX.2000, f1., $V$. Demuer \& E. Bausen 1397 (MBML).

Phyllanthus augustinii pode ser confundido com $P$. niruri devido às folhas oblongas, membranáceas, discolores com ápice arredondado, flores com cinco sépalas e androceu com três estames com filetes completamente livres. Porém em $P$. augustinii as flores femininas são longamente pediceladas (ca. $20 \mathrm{~mm}$ compr.) e possuem disco 5-lobado, enquanto em $P$. niruri as flores femininas têm pedicelo de até $5 \mathrm{~mm}$ compr. e disco inteiro. Outra característica marcante são os estiletes que excedem o tamanho das sépalas (ca. 2,5 mm compr.) em P. augustinii, o que não ocorre nas demais espécies estudadas.

Espécie endêmica do Brasil e encontrada apenas em floresta ombrófila densa na região 
Sudeste (Garbin et al. 2017). Vale ressaltar que só foram encontrados apenas dois registros de coletas, ambos fora de áreas de conservação.

Coletada com flores apenas em setembro.

4. Phyllanthus caparaoensis G.L. Webster, Lundellia 5: 19. 2002.

Tipo: BRASIL. MINAS GERAIS/ESPÍRITO

SANTO: Serra do Caparaó, 1879, H. Wawra 1039

(holótipo US n.v., fotografia do holótipo em US!).

Iconografia: Martins, Lima \& Cordeiro 2014:

Figura 1 g-i.

Ervas monóicas, $0,3-0,5 \mathrm{~m}$ alt.; ramificação filantóide; caule anguloso com emergências formando cristas, ramos plagiotrópicos pinatiformes, cilíndricos, glabros. Folhas subcartáceas, discolores, 1,5-6 × 1,5-6 mm; orbiculares ou elípticas; ápice levemente emarginado; base arredonda; face adaxial glabra; face abaxial pubescente; margem revoluta; nervação broquidodróma; pecíolos 1-1,5 mm compr., pubescentes; estípulas $1-1,5 \mathrm{~mm}$ compr., triangulares, pubescentes. Címulas axilares resumidas a uma única flor; brácteas ca. $1 \mathrm{~mm}$ compr., lanceoladas. Flores masculinas sépalas 5, 1-1,5 mm compr., obovais, membranáceas; alvoesverdeadas; estames 3, filetes livres, anteras com deiscência horizontal; disco 5-lobado; pedicelo 1,5-2 mm compr. Flores femininas sépalas 5, 1,5-2 mm compr., obovais; alvo-esverdeadas; ovário ca. $1 \mathrm{~mm}$ compr., estiletes 3 , bífidos; disco inteiro; pedicelo 1,5-2 mm compr. Cápsulas ca. $3 \times 3$ $\mathrm{mm}$. Sementes 1-1,5 mm compr., castanhas, lisas. Material examinado: Marilândia, 19²0'45"S, 40³2'57'W, XII.2007, fl., V. Demuner et al. 4781 (MBML, SP).

Phyllanthus caparaoensis possui folhas orbiculares ou elípticas, flores de ambos os sexos e androceu com três estames livres, assim como observado em $P$. subemarginatus, porém suas folhas são subcartáceas, discolores, com face abaxial e pecíolos pubescentes. Além disso, o pedicelo das flores femininas possui cerca de 8 $\mathrm{mm}$ de comprimento e as sementes são lisas. Em contrapartida, P. submarginatus apresenta folhas membranáceas, discolores, com face abaxial e pecíolos glabros, o pedicelo das flores femininas com 4-5 mm compr. e sementes verruculosas.

Espécie encontrada na Serra do Caparaó, entre os estados de Minas Gerais e Espírito Santo, e também no estado do Rio de Janeiro onde ocorre em áreas de campos rupestres e nos campos de altitude.
Coletada com flores de janeiro a março, julho, setembro, outubro e novembro e frutos nos meses de janeiro, agosto e novembro.

\section{Phyllanthus caroliniensis Walter, Flora} Caroliniana p. 228. 1788.

Tipo: Herbário Thomas Walter 83 (holótipo BM). Iconografia: Martins, Lima \& Cordeiro 2014: Figura $1 \mathrm{j}-1$.

Ervas monóicas, 0,1-0,4 $\mathrm{m}$ alt.; ramos cilíndricos, glabros, caule liso, sem ramificação filantóide. Folhas dísticas, membranáceas, concolores ou discolores, $8-15 \times 3-8 \mathrm{~mm}$; elípticas ou obovais; ápice arredondado; base cuneada; face adaxial pubescente, tricomas simples; face abaxial glabra; margem plana, nervação cladodróma; pecíolos $0,5-2 \mathrm{~mm}$ compr.; estípulas $1-1,5 \mathrm{~mm}$ compr., triangulares, glabras. Címulas com 2-3 flores, às vezes, flores solitárias; brácteas 1-1,5 $\mathrm{mm}$ compr., estreitamente triangulares. Flores masculinas sépalas 6, 0,5-1 mm compr., ovais, membranáceas, alvo-esverdeadas; estames 3 , filetes livres, anteras com deiscência horizontal; disco 6-lobado; pedicelo 0,5-1 mm compr. Flores femininas sépalas 6, 1-2 mm compr., lanceoladas, membranáceas, alvo-esverdeadas; ovário ca. 0,5 $\mathrm{mm}$ compr., estiletes 3, 2-fidos; disco inteiro; pedicelo ca. $0,5 \mathrm{~mm}$ compr. Cápsulas ca. $1 \times 2 \mathrm{~mm}$. Sementes 1-1,5 mm compr., castanho-amareladas, verruculosas.

Material examinado: Nova Venécia, I.2009, fr., $L$. Kollmann 11367 (MBML).

Apesar de $P$. caroliniensis não possuir ramificação filantóide, pode eventualmente ser confundido com $P$. niruri e $P$. tenellus, que também são espécies ruderais e muitos comuns, porém $P$. caroliniensis possui flores femininas praticamente sésseis, com seis sépalas, enquanto nas outras duas espécies as flores tem cinco sépalas e os pedicelos das flores femininas variam de 2 a $5 \mathrm{~mm}$ de comprimento.

Espécie amplamente distribuída nas Américas, estendendo-se desde o Sudeste dos Estados Unidos até Argentina, incluindo Antilhas (Silva \& Sales 2007). No Brasil, ocorre nas regiões Norte, Nordeste, Sudeste e Sul onde cresce, de acordo com Silva \& Sales (2007), em floresta ombrófila densa atlântica, em áreas de Cerrado (nas matas de galeria), na Caatinga e nas florestas montanas ("brejos de altitude"), borda de florestas estacionais, e também como planta ruderal.

Coletada com flores e frutos de fevereiro a maio e em novembro. 
6. Phyllanthus cladotrichus Müll. Arg., Linnaea 32: 25. 1863.

Tipo: BRASIL. RIO DE JANEIRO: L. Riedel s.n. (holótipo B n.v., fotografia do holótipo em F! (F0BN005022 F); isótipo P, fotografia do isótipo em P!).

Iconografia: Martins, Lima \& Cordeiro 2014: Figura 2a.

Arbustos a arvoretas monóicos, 2,5-7 m alt.; sem ramificação filantoide, caule liso, ramos cilíndricos, achatados apenas na porção terminal, pubescentes. Folhas membranáceas, discolores, 4-12 × 1,5-6 cm; elípticas; ápice cuspidado ou acuminado; base aguda ou arredondada; faces adaxial e abaxial glabras; margem levemente revoluta; nervação broquidodróma; pecíolos 3-5 mm compr.; estípulas 2,5-3,5 mm compr., lanceoladas, glabras ou pubescentes. Címulas axilares, compostas por até 4 flores, às vezes, flores solitárias; brácteas ca. 1,5 mm compr., estreitamente triangulares, glabras a pubescentes. Flores masculinas sépalas 5, 1-1,5 mm compr., largamente ovais, membranáceas, vináceas; estames 2, filetes completamente unidos formando uma coluna, anteras com deiscência horizontal; disco inteiro; pedicelo 4-6 cm compr. Flores femininas sépalas $6,1,5-2 \mathrm{~mm}$ compr., elípticas a ovais, membranáceas, vináceas; ovário ca. 0,5 mm compr., estiletes 3, 2-fidos desde a base; disco inteiro; pedicelo 7-18 cm compr. Cápsulas 4-7 × 5-10 mm. Sementes 4-6 mm compr., castanhas, estriadas.

Material examinado: Linhares, II.1994, fl. e fr., D.A. Folli 2204 (CVRD).

Phyllanthus cladotrichus pode ser reconhecida pelo hábito arbustivo ou arbóreo até $7 \mathrm{~m}$ alt., indumento presente nos ramos, folhas com 4-12 × 1,5-6 cm, flores com sépalas vináceas, as femininas com 7 a $18 \mathrm{~cm}$ compr. de pedicelo, características únicas entre as espécies de Phyllanthus ocorrentes no estado do Espírito Santo.

Espécie endêmica do Brasil, onde ocorre no Nordeste e Sudeste, principalmente em áreas de floresta ombrófila densa atlântica (BFG 2015). Apesar de possuir coletas recentes, nenhuma foi em áreas de conservação.

Coletada com flores nos meses de fevereiro, março, junho, novembro e dezembro e com frutos nos meses de março, junho, setembro e dezembro.
7. Phyllanthus gladiatus Müll. Arg., Linnaea 32: 52. 1863.

Tipo: BRASIL. F. Sellow 814 (holótipo B destruído, fotografia do holótipo em F!); Espírito Santo, 1981, B. Weinberg s.n. (neótipo R!).

Fig. $1 \mathrm{a}, \mathrm{b}$

Arvoreta monóica, 2-4 m alt., caule com cerca de $1,5 \mathrm{~cm}$ de diâm., marcado pelas cicatrizes dos ramos, ramificação filantóide; ramos plagiotrópicos modificados em cladódios, lanceolados com margem conspicuamente crenada, cartáceos com feixes vasculares bem evidentes, agudos no ápice, cuneados na base, glabros, dispostos espiraladamente na porção terminal do caule, cartáceos, 2-4 cm larg. Folhas reduzidas, escamiformes, tanto no caule principal, quanto nos cladódios. Címulas axilares, resumidas a uma única flor; brácteas ca. $1 \mathrm{~mm}$ compr., triangulares. Flores masculinas sépalas 5, 2-2,5 $\mathrm{mm}$ compr., orbiculares, conchadas, creme; estames 3, livres, anteras com deiscência vertical; disco 5-lobado; pedicelo $2 \mathrm{~mm}$ compr. Flores femininas sépalas 6 , arredondadas, conchadas, creme; estiletes 3 , unidos até a metade, disco inteiro, verruculoso, pedicelo ca. $1 \mathrm{~cm}$ compr. Cápsulas ca. $1 \times 1 \mathrm{~cm}$, envoltas pelas sépalas que tornam-se esverdeadas. Sementes $2-3 \mathrm{~mm}$ compr., amareladas, lisas.

Material examinado: Vila Velha, VI.1981, st., $B$. Weinberg 468 (SP).

Material adicional: BRASIL. BAHIA: Itacaré, XII.2015, fl. e fr., I. Cordeiro 3557 (SP)

Esta espécie apresenta os ramos modificados em cladódios assim como Phyllanthus klotzschianus, porém ela é uma arvoreta de floresta ombrófila da floresta, P. klotzschianus é um subarbusto heliófilo que no Espírito Santo cresce no solo arenoso da restinga, os cladódios de P.gladiatus variam de 2 a $4 \mathrm{~cm}$ de largura enquanto em P. klotzschianus de 4 a $8 \mathrm{~mm}$, também as flores masculinas de $P$. klotzschianus são sésseis e as sementes verruculosas, enquanto em $P$. gladiatus tem pedicelos com cerca de $2 \mathrm{~mm}$ de comprimento e as sementes são lisas.

Espécie endêmica do Brasil, encontrada nas regiões Nordeste e Sudeste, onde ocorre em interior de Mata Atlântica. Neste estudo foi coletada em restinga.

Coletada com flores e frutos no mês de fevereiro. 

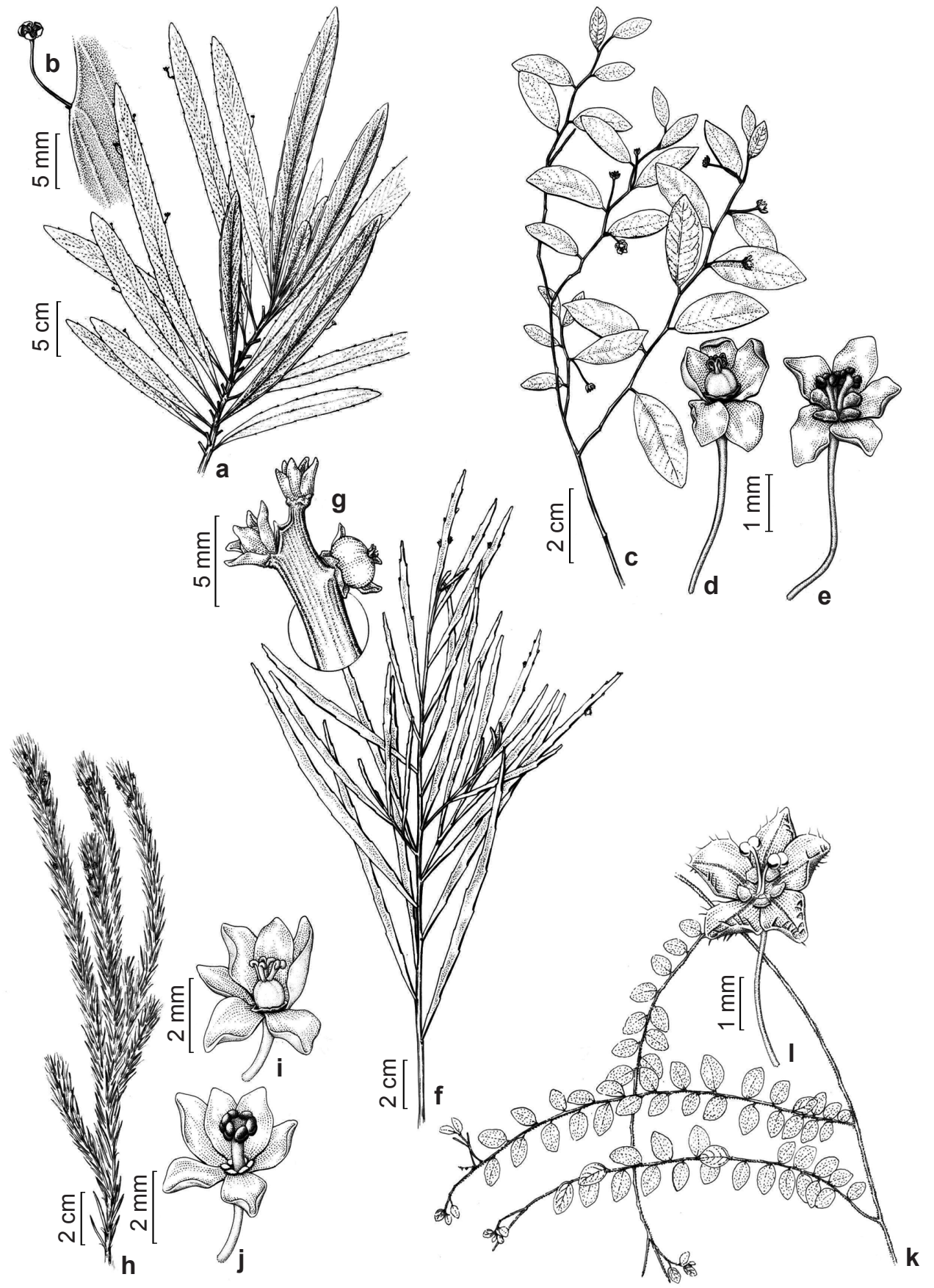

Figura 1 - a,b. Phyllanthus gladiatus - a. ramos modificados em cladódios; b. detalhe da flor com pedicelo longo. c-e. Phyllanthus hypoleucus - c. ramo; d. flor feminina; e. flor masculina. f,g. Phyallanthus klotzschianus - f. ramos modificados em cladódios; g. detalhe do fruto. h-j. Phyllanthus pinifolius - h. ramos; i. flor feminina; $\mathrm{j}$. flor masculina. k,1. Phyllanthus piranii - k. ramo; 1. flor masculina. (a,b. A.M. Amorim 5547; c-e. J.R. Pirani 167; f,g. E.R. Martins 33; h-j. Hatschbach et al; k,1. G. Hatschbach et al. 69170). Ilustrações: Klei Rodrigues.

Figure 1 - a,b. Phyllanthus gladiatus - a. branches modified in cladodes; b. detail of flower with long pedicelo. c-e. Phyllanthus hypoleucus - c. branch; d. female flower; e. male flower. f,g. Phyallanthus klotzschianus - $\mathrm{f}$. branches modified in cladodes; g. detail of fruit. h-j. Phyllanthus pinifolius $-\mathrm{h}$. branches; i. flower female; j. male flower. k,l. Phyllanthus piranii - k. branch; i. male flower (a,b. A.M. Amorim 5547; c-e. J.R. Pirani 167; f,g. E.R. Martins 33; h-j. Hatschbach et al; k,l. G. Hatschbach et al. 69170). Drawings: Klei Rodrigues. 
8. Phyllanthus hypoleucus Müll. Arg., Linnaea 32: 40.1863 .

Tipo: BRASIL. BAHIA: F. Sellow 583 (isosíntipo $\mathrm{G}$ n.v., imagem de $\mathrm{G}$ no JStor!). $\quad$ Fig. 1c-e

Subarbustos a arbustos monóicos, 0,3-1,5 $\mathrm{m}$ alt.; ramos cilíndricos, levemente achatados no ápice, glabros, caule liso, sem ramificação filantoide. Folhas dísticas, membranáceas, discolores, $12-30 \times 4-11 \mathrm{~mm}$; ovais; ápice acuminado a agudo; base acuminada ou aguda; face adaxial glabra; face abaxial pubescente, tricomas simples; margem levemente revoluta; nervação broquidodróma; pecíolos 2-2,5 $\mathrm{mm}$ compr.; estípulas ca. $2 \mathrm{~mm}$ compr., triangulares, glabras. Címulas axilares reduzidas a uma única flor; brácteas ca. 1,5 mm compr., estreitamente triangulares. Flores masculinas sépalas 5, ca. $1 \mathrm{~mm}$ compr., elípticas, membranáceas, alvas; estames 3 , filetes livres, anteras com deiscência vertical; disco 5-lobado; pedicelo 2,5-3,5 mm compr. Flores femininas sépalas 5, 2-2,5 $\mathrm{mm}$ compr., elípticas, membranáceas, alvas; ovário ca. $0,5 \mathrm{~mm}$ compr., estiletes 3, 2-fidos; disco inteiro; pedicelo 11-12 $\mathrm{mm}$ compr. Cápsulas ca. $2,5 \times 3 \mathrm{~mm}$. Sementes 1,5-2 mm compr., castanhas, verruculosas.

Material examinado: Alegre, I.2009, fl., L. Kollmann et al. 11485 (MBML)

Espécie exclusiva do Brasil, onde ocorre em floresta ombrófila densa atlântica nas regiões Nordeste e Sudeste desde o nível do mar até e $1.000 \mathrm{~m}$ de altitude (Webster 2002b; Silva \& Sales 2008). Vale ressaltar que há poucos registros de coletas, sendo apenas uma registrada na Estação Biológica de Mestre Álvaro no Município de Serra no Espírito Santo.

Coletada com flores e frutos nos meses de janeiro e novembro.

\section{Phyllanthus klotzschianus Müll. Arg., Linnaea} 32: 53. 1863.

Tipo: BRASIL. P. Claussen 786 (lectótipo C n.v., estabelecido por Santiago et al. (2006)).

Fig. 1f,g

Subarbustos monóicos, com ramificação filantóide, 0,2-0,8(-2) $\mathrm{m}$ alt.; ramos modificados em cladódios, 4-8 $\mathrm{mm}$ de larg., glabros, caule liso. Folhas com limbo desenvolvido presentes apenas nas plantas jovens, dísticas, membranáceas, 5-9 × 2-4 mm; obovais ou elíptico-lanceoladas; ápice obtuso; base aguda ou obtusa; faces adaxial e abaxial glabras; pecíolos 1-2 mm compr.; estípulas ca. $1 \mathrm{~mm}$ compr., glabras; na maior parte das planta as folhas são reduzidas a estruturas escamiformes. Címulas axilares, (1-)3 flores; brácteas ca. $0,5 \mathrm{~mm}$ compr., triangulares. Flores masculinas sépalas 5, 1,5-2 mm compr., elípticas ou oblongas, membranáceas, alvas; estames 3 , filetes completamente unidos formando uma coluna, anteras com deiscência vertical; disco 5-lobado, subsésseis. Flores femininas sépalas 5, 2,5-3 mm compr., elípticas, membranáceas, alvas; ovário ca. $1 \mathrm{~mm}$ compr., estiletes 3, 2-fidos até a metade; disco inteiro; pedicelos inconspícuos, subsésseis. Cápsulas ca. 2,5 × $3 \mathrm{~mm}$. Sementes 1,5-2 mm compr., castanhas, verruculosas.

Material examinado: Vila Velha, XI.2011, fl. e fr., E.R. Martins et al. 33 (SP).

Comentários sobre a semelhança entre $P$. klotzschianus e P. gladiatus em P. gladiatus.

Espécie endêmica do Brasil encontrada no Nordeste, Centro-Oeste e Sudeste. Habita campos rupestres e restingas, geralmente ocorrendo em fendas de rochas areníticas ou solos arenosos (Cordeiro 1992; Silva \& Sales 2008).

Coletada com flores e frutos durante todos os meses do ano.

10. Phyllanthus niruri L., Species Plantarum 2: 981. 1753.

Tipo: Herb. Clifford 440, Phyllanthus n. 2 (lectótipo BM n.v., fotografia do lectótipo em BM!). Iconografia: Martins, Lima \& Cordeiro 2014: Figura 2 e-f.

Ervas monóicas, 5-20 cm alt.; glabra; com ramificação filantóide, caule liso, ramos cilíndricos. Folhas membranáceas, discolores, 2-12(-19) × 1,56(-10) mm; oblongas; ápice arredondado, apiculado; base assimétrico-cordada; faces adaxial e abaxial glabras; margem plana; nervação cladodróma; pecíolos 1-1,5 mm compr; estípulas 1-2 mm compr., triangulares ou lineares, glabras. Címulas axilares reduzidas a uma única flor; brácteas $1-4 \mathrm{~mm}$ compr., lineares. Flores masculinas sépalas 5, 1,5-2 mm compr., obovais, membranáceas; alvo-esverdeadas; estames 3, filetes livres, anteras com deiscência horizontal; disco 5-lobado; pedicelo 2,5-4 mm compr. Flores femininas sépalas 5, 2-3 mm compr., obovais a largamente obovais, membranáceas; alvoesverdeadas; ovário ca. 0,5 mm compr., estiletes 3 , 2-fidos até a metade; disco inteiro; pedicelo 2-5 $\mathrm{mm}$ compr. Cápsulas ca. $2 \times 3 \mathrm{~mm}$. Sementes 1-1,5 mm compr., castanhas, verruculosas. 
Material examinado: Santa Tereza, 1950'48"S, 4043'10"W, I.2002, fl., J.R. Pirani et al. 4924 (SPF).

Phyllanthus niruri pode ser confundida com Phyllanthus urinaria, outra espécie encontrada no Espírito Santo, da qual se diferencia principalmente por seus frutos lisos, quem em $P$. urinaria são ornamentados e também com $P$. augustinii, que, entretanto, possui flores femininas com pedicelos de $20 \mathrm{~mm}$ de comprimento e disco 5-lobado versus pedicelos com 2-5 $\mathrm{mm}$ e disco inteiro nas flores femininas de $P$. niruni.

Ocorre desde os Estados Unidos até a Argentina e Antilhas (Webster 1970). Ocorre em todo o território nacional em campo cerrado, campo rupestre, borda de floresta ombrófila densa e de floresta ombrófila mista, além de ocorrer também como ruderal em culturas ou terrenos abandonados (BFG 2015).

Coletada com flores e frutos em todos os meses do ano.

11. Phyllanthus orbiculatus L.C. Rich., Actes de la Société d'Histoire Naturelle de Paris 1: 113. 1792

Tipo: GUIANA FRANCESA. Cayenne: Leblond s.n. (holótipo P n.v., fotografia do holótipo em P! (P00609701)).

Iconografia: Martins, Lima \& Cordeiro 2014: Figura 2 g-h.

Ervas monóicas, 0,1-1,5 m alt.; com ramificação filantóide, caule liso, ramos angulosos. Folhas membranáceas, levemente discolores, 3-9 × 3-9 mm; orbiculares ou ovais; ápice cuspidado ou obtuso; base arredondada; face adaxial glabra; face abaxial glabra; margem plana; nervação cladodróma; pecíolos $1-1,5 \mathrm{~mm}$ compr.; estípulas ca. $1 \mathrm{~mm}$ compr., lanceoladas, glabras. Címulas axilares, compostas geralmente por 2 flores; brácteas ca. $1 \mathrm{~mm}$ compr., lanceoladas. Flores masculinas sépalas 6, 1-1,5 mm compr., elípticas, membranáceas, vináceas; estames 3 , filetes livres, anteras com deiscência horizontal; disco 6-lobado; pedicelo 1,5-3 mm compr. Flores femininas sépalas 6 , ca. $1 \mathrm{~mm}$ compr., elípticas, membranáceas, vináceas; ovário ca. $0,5 \mathrm{~mm}$ compr., estiletes 3, 2-fidos; disco 6-lobado; pedicelo 1,5-9 mm compr. Cápsulas ca. $2 \times 2 \mathrm{~mm}$. Sementes 1-2 $\mathrm{mm}$ compr., castanho-amareladas, verruculosas. Material examinado: Nova Venécia, XI.2009, fl., Forzza, R.C. Forzza et al. 5765 (RB, SP, MBML).
Esta espécie, como o próprio epíteto sugere, possui folhas orbiculares, estas geralmente avermelhadas ou vináceas, com a face abaxial recoberta por tricomas alvos, especialmente sobre as nervuras e na linha mediana das sépalas. Phyllanthus orbiculatus pode ser confundida com $P$. subemarginatus em virtude da forma semelhante de suas folhas e do androceu com três estames livres, entretanto suas folhas avermelhadas e flores vináceas com seis sépalas e disco 6-lobado da flor feminina a diferenciam de $P$. subemarginatus que possui folhas e flores esverdeadas e disco da flor feminina inteiro.

Phyllanthus orbiculatus ocorre em toda a América do Sul e Antilhas (Gillespie 1993; Silva \& Sales 2007; Webster 1956). No Brasil, ocorre nas regiões Norte, Nordeste, Centro-Oeste, Sudeste e Sul, de acordo com Webster (1957), em floresta ombrófila densa amazônica e atlântica, Cerrado e em áreas de borda de floresta estacional semidecidual.

Coletada com flores e frutos de janeiro a julho e de outubro a novembro.

12. Phyllanthus pinifolius Baill., Adansonia 5: 353. 1865.

Tipo: BRASIL. PARANÁ: A.St. Hilaire 1599 (holótipo P n.v., fotografia do holótipo em P!).

Fig. $1 \mathrm{~h}-\mathrm{j}$

Subarbustos monóicos, 0,1-0,7 $\mathrm{m}$ alt.; ramos cilíndricos, pubescentes, tricomas simples, caule liso, sem ramificação filantóide. Folhas espiraladas, coriáceas, concolores, 4-12 $11 \mathrm{~mm}$; lineares; ápice acuminado ou agudo, apiculado; base aguda ou atenuada; faces adaxial e abaxial glabras a pubescentes, tricomas simples; margem revoluta; nervação hifódroma; pecíolos 1-1,5 mm compr.; estípulas 2,5-5 mm compr., triangulares, glabras. Címulas axilares reduzidas a uma única flor, às vezes, 2 ; brácteas $2,5-5 \mathrm{~mm}$ compr., triangulares. Flores masculinas sépalas 6, 1,5-2 mm compr., elípticas ou obovais, membranáceas, alvas; estames 3 , filetes completamente unidos formando uma coluna, anteras com deiscência horizontal; disco 6-lobado; pedicelo 2,5-3 mm compr. Flores femininas sépalas $6,2,5-3 \mathrm{~mm}$ compr., elípticas ou obovais, membranáceas, alvas; ovário ca. $1 \mathrm{~mm}$ compr., estiletes 3, 2-fidos apenas no ápice; disco inteiro; pedicelo 2,5-3 mm compr. Cápsulas ca. $5 \times 2 \mathrm{~mm}$. Sementes 1,5-2 $\mathrm{mm}$ compr., castanhas, verruculosas.

Material examinado: Iúna, Parque Nacional do Caparaó, II.2000 (fl), V.C. Souza et al. 23405 (ESA). 
As folhas de Phyllanthus pinifolius são espiraladas, coriáceas, e lineares, características que a distingue das outras espécies que ocorrem no Espírito Santo e auxiliam na sua identificação. A grande maioria das coleções dessa espécie é proveniente de Minas Gerais, do Parque Nacional do Caparaó, na Serra da Mantiqueira, nos limites entre Minas Gerais e Espírito Santo. Atualmente, portanto, a espécie pode ser considerada endêmica da Serra do Caparaó, crescendo entre rochas em campos de altitude nos limites entre os estados de Minas Gerais e Espírito Santo.

Coletada com flores de janeiro a abril, julho a setembro e novembro e dezembro e com frutos em fevereiro, março e agosto.

13. Phyllanthus piranii G.L. Webster, Lundellia 5: 19. 2002.

Tipo: BRASIL. ESPÍRITO SANTO: Conceição de Castelo, BR-262, Km 116, XI.1982, J.R. Pirani, $O$. Yano \& D.F. Santos 230 (holótipo SP!; isótipo SPF!).

Fig. $1 \mathrm{k}, 1$

Ervas monóicas, ca. 0,3 m alt.; ramos cilíndricos, pubescentes, tricomas simples, caule liso, sem ramificação filantóide. Folhas dísticas, membranáceas, discolores, 8-15 × 7-13 mm; ovais; ápice arredondado, às vezes apiculado; base arredondada; faces adaxial e abaxial pubescentes, tricomas simples; margem plana; nervação cladodróma; pecíolos 1-1,5 mm compr.; estípulas 2,5-3 mm compr., triangulares, pubecentes, tricomas simples. Címulas axilares reduzidas a uma única flor; brácteas $2,5-3 \mathrm{~mm}$, lanceoladas. Flores sépalas 5, ca. 0,5 $\mathrm{mm}$ compr., elípticas, membranáceas, alvas; estames 2, filetes livres, anteras com deiscência horizontal; disco 5-lobado; pedicelo 2,5-3 mm compr. Flores femininas sépalas 5, 1,5-2 mm compr., elípticas, membranáceas, alvas; ovário ca. $0,5 \mathrm{~mm}$ compr., estiletes 3,2 -fidos até a metade; disco inteiro; pedicelo $1-1,5 \mathrm{~mm}$ compr. Cápsulas ca. $7 \times 6 \mathrm{~mm}$. Sementes 2,5-3 mm compr., castanho avermelhadas, estriadas.

Material examinado: Conceição do Castelo, V.1999, fl., G. Hatschbach et al. 69170 (SPF).

Phyllanthus pirani se relaciona morfologicamente com P. arenicola, conforme os comentários desta última.

Espécie endêmica do estado do Espírito Santo, crescendo em paredões rochosos em meio a floresta ombrófila densa. Há registro de poucas coletas na localidade tipo, que não é uma área de conservação.
Coletada com flores nos meses de maio e novembro e frutos em novembro.

14. Phyllanthus stipulatus (Raf.) G.L. Webster, Contributions of the Gray Herbarium of the Harvard University 176: 53. 1955.

Tipo: JAMAICA. O. Swartz s.n. (Lectótipo S n.v. S-R-3640, fotografia do lectótipo em S!).

Iconografia: Martins \& Lima 2012: Figura 2g.

Ervas monóicas, 0,2-0,5 m alt.; ramos cilíndricos, pubescentes, tricomas simples, caule liso, com ramificação filantóide. Folhas dísticas, membranáceas, levemente discolores, 3-7 × 1-5 mm; elípticas, oblongas ou obovais; ápice apiculado, arredondado ou obtuso; base aguda ou arredondada; faces adaxial e abaxial pubescentes, tricomas simples; margem levemente revoluta; nervação cladodróma; pecíolos $0,5-1 \mathrm{~mm}$ compr.; estípulas 1-1,5 mm compr., lanceoladas, glabras. Címulas axilares reduzidas a uma única flor; brácteas $0,5-1 \mathrm{~mm}$ compr., lanceoladas. Flores masculinas sépalas 5, 1-1,5 mm compr., obovais, membranáceas, alvas; estames 3 , filetes completamente unidos formando uma coluna coluna, anteras com deiscência horizontal; disco 5-lobado; pedicelo 0,5-1 mm. Flores femininas sépalas $5,1-1,5 \mathrm{~mm}$ compr., obovais a ovais, membranáceas, alvas; ovário ca. $0,5 \mathrm{~mm}$ compr., estiletes 3, 2-fidos apenas no ápice; disco inteiro; pedicelo 1-1,5 mm compr. Cápsulas ca. $3 \times 1,5$ $\mathrm{mm}$. Sementes 1-1,5 mm compr., castanhoamareladas, estriadas.

Material examinado: Santana, XII.1962, fr., J. Mattos \& H. Bicalho 10775 (SP).

Entre as espécies herbáceas do sudeste, é a única que ocorre preferencialmente em solos encharcados de brejos e beira de rios, apresentando inclusive, a porção inferior do caule com um espesso aerênquima esponjoso. Vegetativamente é muito semelhante a $P$. niruri, porém suas flores tem três estames unidos, enquanto em $P$. niruri são livres.

Ocorre desde o sudeste dos Estados Unidos, incluindo as Antilhas, até a Região Sul do Brasil, especialmente em locais paludosos de ambientes florestais (Webster 1970, 2002b). No Brasil é encontrada de Norte a Sul, em floresta ombrófila atlântica e amazônica em várzeas, brejos e áreas de restinga. Coletada com flores nos meses de fevereiro, março, junho e setembro e com frutos nos meses de fevereiro a abril e setembro a outubro. 
15. Phyllanthus subemarginatus Müll. Arg., Linnaea 32(4): 39. 1863.

Tipo: BRASIL. RIO DE JANEIRO: Vauthier 84 (lectótipo W n.v., referido por Webster (2002b)).

Iconografia: Martins, Lima \& Cordeiro 2014: Figura 3d.

Ervas monóicas, 0,5-1,5 m alt.; sem ramificação filantóide, caule liso, ramos longos e delgados, cilíndricos, glabros. Folhas membranáceas, levemente discolores, 4-25 $\times$ 3-19 $\mathrm{mm}$; orbiculares; ápice arredondado, apiculado; base arredondada; faces adaxial e abaxial glabras; margem revoluta; nervação broquidodróma; pecíolos 1,5-2 mm compr.; estípulas ca. $0,5 \mathrm{~mm}$ compr., triangulares, glabras. Címulas axilares, compostas por 3 flores ou, às vezes, flores solitárias; brácteas ca. $0,5 \mathrm{~mm}$ compr., triangulares. Flores masculinas sépalas 5, 1-1,5 mm compr., obovais, membranáceas; alvoesverdeadas; estames 3, filetes livres, anteras com deiscência vertical; disco 5-lobado; pedicelo 2,5-3 $\mathrm{mm}$ compr. Flores femininas sépalas 5, 1-2 mm compr., obovais, membranáceas; alvo-esverdeadas; ovário ca. 0,5 mm compr., estiletes 3, 2-fidos; disco inteiro; pedicelo 3-5(-6) mm compr. Cápsulas ca. $2 \times 2,5 \mathrm{~mm}$. Sementes ca. $1 \mathrm{~mm}$ compr., castanhas, verruculosas.

Material examinado: Piuma, 2052’'S, 4046’W, I.1993, fl., J.A. Kallunki \& J.R. Pirani 330 (SPF).

Phyllanthus subemarginatus é semelhante à $P$. orbiculatus, pois ambas possuem folhas orbiculares e hábito herbáceo. Porém, em $P$. subemarginatusas as flores possuem cinco sépalas e o disco das flores femininas é inteiro, enquanto em P. orbiculatus possuem seis sépalas e o disco é 6-lobado.

Espécie endêmica do leste do Brasil (Silva \& Sales 2008), na floresta ombrófila densa atlântica e Cerrado, matas ciliares e afloramentos rochosos.

Coletada com flores nos meses de janeiro a março (Webster 2002b) e em novembro.

16. Phyllanthus tenellus Roxb., Flora Indica 2(3): 668. 1882.

Tipo: INDIA. West Bengal Calcutta Botanical Garden, Wallich 7892 (holótipo K n.v., referido por Webster (2001)).

Iconografia: Martins, Lima \& Cordeiro 2014: Figura 3e-f.

Ervas monóicas, 0,1-1 m alt.; com ramificação filantóide, caule liso, ramos cilíndricos, achatados na porção terminal, glabros. Folhas membranáceas, levemente discolores, 5-15 × 3-8 $\mathrm{mm}$; elípticas ou obovais; ápice arredondado ou obtuso; base aguda; faces adaxial e abaxial glabra; margem plana; nervação cladodróma; pecíolos $0,5-1 \mathrm{~mm}$ compr.; estípulas 1-2 mm compr., triangulares, glabras. Címulas axilares, compostas, em geral, por 2 flores, ou, às vezes, flores solitárias; brácteas 1-2 mm compr., triangulares. Flores masculinas sépalas 5, 1-1,5 mm compr., obovais, membranáceas; alvo-esverdeadas; estames 5(-6), filetes livres, anteras com deiscência vertical; disco 5(-6) lobado; pedicelo 1-1,5 mm. Flores femininas sépalas $5,0,5-1 \mathrm{~mm}$, ovais a triangulares, membranáceas; alvo-esverdeadas; ovário ca. 0,5 mm compr., estiletes 3, 2-fidos; disco inteiro, pouco desenvolvido; pedicelo 3-4 mm compr. Cápsulas $1-1,5 \times 1,5-2 \mathrm{~mm}$. Sementes $0,5-1 \mathrm{~mm}$ compr., castanho-amareladas, verruculosas.

Material examinado: Linhares, Reserva Florestal de Linhares, V.1996, fl. e fr., D.A. Folli 2740 (CVRD).

Espécie amplamente distribuída nos trópicos de todo o globo. De acordo com Webster (2001), na região neotropical ocorre no México, leste dos Estados Unidos, Antilhas e América do Sul. No Brasil ocorre em todas as regiões em floresta ombrófila atlântica a amazônica, em campo, capoeira e principalmente como espécie invasora (BFG 2015).

Coletada com flores e frutos em todos os meses do ano, com exceção de setembro.

17. Phyllanthus urinaria L., Species Plantarum 2: 982.1753.

Tipo: INDIA. Herbarium Hermann (BM).

Ervas monóicas, ca. $0,5 \mathrm{~m}$ alt., ramos cilíndricos, glabros, caule liso, com ramificação filantóide. Folhas dísticas, membranáceas, levemente discolores, 10-14 × 3-4 mm; elípticas ou oblongas ou obovais; ápice arredondado; base assimétrica, cordata; faces adaxial e abaxial glabras; margem levemente revoluta; nervação cladodróma; pecíolos 0,5-1 mm compr.; estípulas 1-1,5 mm compr., triangulares, glabras. Címulas compostas, geralmente, por 2-3 flores; brácteas 1-4 mm compr., triangulares. Flores masculinas sépalas 6 , ca. $0,5 \mathrm{~mm}$ compr., elípticas ou obovais, membranáceas, alvas; estames 3 , filetes completamente unidos formando uma coluna, anteras com deiscência vertical; disco 6-lobado; pedicelo $0,5-1 \mathrm{~mm}$ compr. Flores femininas sépalas 6 , ca. $0,5 \mathrm{~mm}$ compr., lanceoladas, membranáceas, alvas; ovário ca. $0,5 \mathrm{~mm}$ compr., ornamentado, estiletes 3, 2-fidos até a metade; disco inteiro; pedicelo $1-1,5 \mathrm{~mm}$ compr. Cápsulas ca. $2 \times 3$ 
mm, ornamentada. Sementes 1-1,5 mm compr., castanho-amareladas, estriadas.

Material examinado: Nova Venécia, 1847'14"S, $40^{\circ} 26^{\prime} 44^{\prime \prime}$, I.2009, fr., L. Kollmann \& A.P. Fontana 11367 (MBML).

Única espécie do gênero que possui ovário e fruto ornamentados, já que nas demais são lisos.

Phyllanthus urinaria é uma espécie pantropical, naturalizada em vários continentes, na região neotropical é referida para as Antilhas, Guianas, Guatemala, Honduras, Panamá, Venezuela e Brasil (Webster 1956; Rossignol et al. 1987). No Brasil, ocorre em todas as regiões em floresta ombrófila densa amazônica e atlântica e em áreas de Cerrado, bordas de mata e como ruderal (Silva \& Sales 2007). Pode ser encontrada também nas bordas de florestas de restinga.

Coletada com flores no mês de março e abril e com frutos em março.

\section{Agradecimentos}

À Coordenação de Aperfeiçoamento de Pessoal de Nível Superior (CAPES), a bolsa de mestrado concedida por meio do projeto PROTAX. Ao Instituto de Botânica da Secretaria do Meio Ambiente do Estado de São Paulo e ao Centro de Ciências Agrárias da Universidade Federal de São Carlos, todo apoio e estrutura concedidos para realização desse trabalho. Ao ilustrador Klei Rodrigo Souza, a elaboração das ilustrações e da arte final

\section{Referências}

Allem AC (1977) Notas sistemáticas y nuevos sinónimos en Euphorbiaceae de América del Sur - VII. Revista Brasileira de Biologia 37: 483-497.

BFG - The Brazil Flora Group (2015) Growing knowledge: an overview of seed plant diversity in Brazil. Rodriguésia 66: 1085-1113.

Chase MW, Soltis DE, Olmstead RG, Morgan D, Les DH, Mishler BD, Duvall MR, Price RA, Hills HG, Qiu YL, Kron KA, Rettig JH, Conti E, Palmer JD, Manhart JR, Sytsma KJ, Michaels HJ, Kress WJ, Karol KH, Clarck WD, Hedrén M, Gaut BS, Jansen RK, Kim KJ, Wimpee CF, Smith JF, Furnier GR, Strauss SH, Xiang QY, Plunkett GM, Soltis PS, Swensen SM, Willians SE, Gadek PA, Quinn CJ, Eguiarte LE, Golenberg E, Learn JR, Graham SW, Barrett SCH, Dayanandan S \& Albert VA (1993) Phylogenetics of seed plants: an analysis of nucleotide sequences from plastide gene rbcL. Annals of the Missouri Botanical Garden 80: 528-580.

Chase MW, Zmartzty S, Lledó MD, Wurdack KJ, Swesen SM. \& Fay MF (2002) When in doubt, put it in Flacourtiaceae: a molecular phylogenetic analysis based on plastid rbcL DNA sequences. Kew Bulletin 57: 141-181.

Cordeiro I (1992) Flora da Serra do Cipó, Minas Gerais: Euphorbiaceae. Boletim de Botânica da Universidade de São Paulo 13: 169-217.

Cordeiro I (2004) Flora de Grão-Mongol, Minas Gerais: Euphorbiaceae. Boletim de Botânica da Universidade de São Paulo 22: 109-131.

Garbin ML, Saiter FZ, Carrijo, TT \& Peixoto AL (2017) Breve histórico e classificação da vegetação capixaba. Rodriguésia 68: 1883-1894.

Gillespie LJ (1993) Euphorbiaceae of the Guianas: Annotated Species Checklist and Key to the Genera. Brittonia 45: 56-94.

Govaerts R, Frodin DG \& Radcliffe-Smith A (2000) World checklist and bibliography of Euphorbiaceae (and Pandaceae) 4. Royal Botanic Gardens, Kew. Pp. 1257-1355.

Hofmann P, Kathriarachchi H \& Wurdack KJ (2006) A phylogenetic classification of Phyllanthaceae (Malpighiales; Euphorbiaceae sensu lato). Kew Bulletin 61: 37-53.

Judd WS, Campbell CS, Kellogg EA \& Stevens PF (2009) Sistemática vegetal: um enfoque filogenético. Artmed, Porto Alegre. Pp. 355-359.

Katriarchchi H, Samuel R, Hoffmann P, Mlinarec J, Wurdack KJ, Ralimanna H, Stuessy TF \& Chase MW (2006) Phylogenetics of the tribe Phyllantheae (Phyllanthaceae; Euphorbiaceae sensu lato) based on ITS and plastid matk DNA sequence data. American Journal of Botany 93: 637-655.

Martins ER \& Lima LR (2011) Sinopse do gênero Phyllanthus (Phyllanthaceae) do estado de São Paulo. Hoehnea 38: 123-133.

Martins ER \& Lima LR (2012) Flora fanerogâmica do estado de São Paulo. Instituto de Botânica, São Paulo. Vol. 7, pp. 250-259.

Martins ER, Lima LR. \& Cordeiro I (2014) Phyllanthus (Phyllanthaceae) no estado do Rio de Janeiro. Rodriguésia 65: 405-424.

Mueller JA (1873) Euphorbiaceae. In: Martius CFP \& Eichler AG (eds.) Flora brasiliensis. Typographia Regia, Monachii. Vol. 11, pars 2, pp. 1-752.

Rossignol L, Rossignol M \& Haicour R (1987) A systematic revision of Phyllanthus subsection Urinaria (Euphorbiaceae). American Journal of Botany 74: 1853-1862.

Secco RS, Cordeiro I \& Martins ER (2010) In: Forzza RC et al. (org.) Catálogo de plantas e fungos do Brasil. Vol. 2. Andrea Jakobsson Estúdio, Instituto de Pesquisas Jardim Botânico do Rio de Janeiro, Rio de Janeiro. Pp. 1439-1442.

Silva MJ \& Sales MF (2007) Phyllanthus L. (Phyllanthaceae) em Pernambuco. Brasil. Acta Botanica Brasilica 21: 79-98.

Silva MJ \& Sales MF (2008) Sinopse do gênero Phyllanthus (Phyllanthaceae) no nordeste do Brasil. Rodriguésia 59: 407-422. 
Simões CMO, Mentz LA, Schenkel EP, Irgang BE \& Stehmann JR (1986) Plantas da medicina popular no Rio Grande do Sul. UFRGS, Porto Alegre. Pp. $60,72,73$.

Smith LB, Downs RJ \& Klein RM (1988) Phyllanthus. In: Reitz R. (ed.) Flora ilustrada catarinense. Primeira parte monografia: as plantas Euphorbiáceas (EUFO). Herbário Barbosa Rodrigues (HBR), Itajaí. pp. 27-57.

Thiers B [continuamente atualizado] Index Herbariorum: a global directory of public herbaria and associated staff. New York Botanical Garden's Virtual Herbarium. Disponível em $<$ http://sweetgum.nybg. org/ih/> . Acesso em 20 julho 2016.

Torres DSC, Cordeiro I \& Giulietti AM (2003) O gênero Phyllanthus L. (Euphorbiaceae) na Chapada Diamantina, Bahia, Brasil. Acta Botanica Brasilica 17: 265-278.

Webster GL (1956) A monographic study of the West Indian species of the Phyllanthus L. Journal of the Arnold Arboretum 37: 91-122.

Webster GL (1957) A monographic study of the West Indian species of the Phyllanthus L. Journal of the Arnold Arboretum 38: 51-79.

Webster GL (1959) Phyllanthus L. Anais Botânicos do Herbário Barbosa Rodrigues 11: 164-170.
Webster GL (1967) The genera of Euphorbiaceae in the south-eastern United States. Journal of the Arnold Arboretum 48: 303-430.

Webster GL (1970) Revision of the Phyllanthus (Euphorbiaceae) in the continental United States. Brittonia 22: 44-76.

Webster GL (2001) Synopsis of Croton and Phyllanthus (Euphorbiaceae) in Western Tropical Mexico. Contributions from the University of Michigan Herbarium 23: 353-388.

Webster GL (2002a) Three new sections and a new subgenus of Phyllanthus (Euphorbiaceae). Novon 12: $290-298$.

Webster GL (2002b) A synopsis of the Brazilian taxa of Phyllanthus section Phyllanthus (Euphorbiaceae). Lundellia 5: 1-26.

Webster GL (2003) A synopsis of the Phyllanthus section Nothoclema (Euphorbiaceae). Lundellia 6: 9-36.

Wurdack KJ, Hoffman P, Samuel R, Bruijin A, Bank MV \& Chase MW (2004) Molecular phylogenetic analysis of Phyllanthaceae (Phyllanthoideae pro parte, Euphorbiaceae sensu lato) using plastid rbcL DNA sequences. American Journal of Botany 91: 1882-1900.

\section{Lista de exsicatas}

Ab A 320 (15). Abrantes HXBH9455 (1). Abreu CB 1 (15). Aguillar 128 (15), R100007 (15). Almeida J 1668 (14). Almeida TE 1703 (15). Alves M 130 (2), 205 (14), 1776 (14), R169350 (14). Alves MVS 333 (14). Alves TMA 230 (14). Amaral MCE SPF 19820 (1), SP259136 (1). Amorim AM 3377 (6). Amorim AMA 7791 (14). Anderson WR 8743 (10), 8914 (14), 9171 (13), 9243 (14), 35931 (14), 36324 (10). Andrade AG 1877 (2). Andrade IR 28 (14). Andrade P 494 (1). Andreata RHP 541 (14). Angeli C 54 (14). Aona LY 97/105 (9). Araújo AO 242 (10). Araújo DSD 52 (2), 700 (2). Araújo GM 1053 (1). Arbo MM 4217 (10), 4874 (10), 5067 (9). Arruda R 254 (1). Assis V 141 (15). Augustin JO CESJ 35082 (1). Azevedo 9 (15). Bacchi EM RB205110 (15), SP169625 (15). Barbosa M 2208 (14). Barreto KD SP444587 (10). Barreto M 1191 (11), 2627 (10), 2628 (10), 2632 (14), 2639 (14), 5053 (14), 9762 (14), 9764 (14), 10173 (15). Barros AAM 1663 (14), 2569 (14). Barros F 2639 (10). Barros WD 1119 (14). Batalha MA 1359 (10). Batista HP 167 (2). Bernacci LC 10 (5), 1823 (1), 23999 (10). Bertoni JEA 23514 (1). Bicudo LRH 449 (10). Boechat AP 1 (10). Boone W 59 (15), 562 (15), 672 (4), 868 (6), 976 (4). Bouzadas CP 74 (14). Bovini MG 419 (14). Brade AC 9895 (14), 10455 (14), 11002 (2), 11107 (14), 11703 (15), 12461 (14), 12967 (14), 13583 (10), 15848 (6), 16989 (14), 19329 (14), 19465 (14), 19830 (14), 20034 (14), 20526 (10). Braga JMA 3574 (14). Brandão M 11495 (15), 12554 (10), 19532 (15), 19536 (15), 19539 (15), 20780 (15), 21627 (10), 24159 (10), 25353 (14), 28969 (15), 29267 (15), 29334 (15). Brina AE 32783 (1), BHCB32783 (1), BHCB34972 (10), ESA71333 (1), SPF137968 (1). Brisch AM PMSP7227 (15). Buendia JPL PAMG2663 (10). Buendia L 523 (15), 550 (15), 1000 (10). Campêlo CR 869 (15), Campos DL 53 (15), 54 (15), 55 (15), 57 (15), 5962 (15), 63 (15), 65 (15), 66 (15), 69 (15), R185356 (15), R185357 (15), R185730 (15), R185734 (15). Campos MTVA CFCR13240 (10). Campos PP 236 (14), 413 (14), 480 (14), 2786 (14). Capelato MSFS 258 (15). Carauta JPP 74 (14), 568 (14), 1814 (14), 2337 (14), 2729 (14), 3249 (14), 5424 (14), 7503 (15), R157987 (10). Carmo FF 483 (14), 912 (14), 1319 (14), 1557 (14), 1925 (2), 1976 (2), 2085 (9), 3596 (2), 3880 (14), 4209 (2), 5101 (2), 5103 (14). Caruzo MBR 25 (10), 26 (10), 46 (10). Carvalho AF 270 (15). Castellanos A 24356 (15), 24456 (15), R197678 (15). Castelois I 366 (1). Cavalcanti DC 275 (13), 276 (13), 277 (13). Cavalcanti TB CFCR9537 (10), UEC45906 (14). Ceccantini GC 3036 (1). Christo AG 344 (15). Coelho LBV 26 (15). Coleman MA 141a (15). Cordeiro I 471 (15), 524 (14), 1451 (14), 2790 (14), 2807 (15), CFSC1186 (11), CFSC6110 (10), CFSC6145 (10), CFSC6425 (2), CFSC6792 (10), CFCR8845 (14), CFSC10605 (10), CFCR11322 (14), CFCR11593 (14), CFSC11186 (11), CFSC43546 (14), UEC 48515 (14), UEC48510 (10), CFCR64506 (14), SP259097 (14). Costa IRM 173 (14). Costa MP 20 (13), 38 (14). Costa MS 220 (2). Cruz ND 6181 (10). Cunha LHS 594 (15), 1285 (10). Damazio L 1776 (14). Dedecca DM 418 (15). Demuner V 255 (8), 991 (14), 1397 (3), 1423 (14), 1614 (4), 3879 (4), 4781 (4). Dias IS RBR19249 (15). Diniz AF UFOP6840 (15). Duarte AP 3751 (4), 4046 (14), 4120 (14), 4168 (14), 7455 (10), 7533 (1), 8978 (14), 9079 (10), 14073 (1), 13932 (14). Duker J 202 (14). Echtemacht L 227 (1). Egler WA 32 (15), 35 (15), RB90337 (14). Eiten G 1231 (10), 2119 (10), 2524 (10), 2750 (5), 2751 (15), 2944 (10), 2947 (10), 3465 (15), 
5625 (10), 5949 (15), 6261 (14), 7204 (14), 7206 (14), 7875 (15). Emelen A 23 (15). Emmerich M 34 (14), 259 (14), 2855 (1), 2856 (14), 3358 (14), 3683 (13), R157953 (10). Emygdio L 1174 (14), 3331 (14). Esgario C 30 (14). Esteves GL SP259109 (1), SPF34971 (1). Esteves R 214 (14). Faria C R40558 (14). Farney C 623 (14), 1214 (14), 4102 (14), 4376 (14). Fernandes BHQ 1412 (4), 1711 (14), 2735 (15). Ferreira RR 77 (14). Ferreira SFR 157952 (14). Ferreira VF 1258 (13), 1358 (14), 1844 (14), 1944 (14). Ferreira WM 871 (1). Figueiredo JO 1952 (14), 1954 (14). Folli DA 2204 (6), 2740 (15). Fonseca ML 1852 (10). Fontana AP 720 (14), 4868 (14), 5066 (14), 5073 (14), 5228 (14), 5957 (4). Fontella PJ 417 (2). Forzza RC 2818 (14), 3748 (10), 5175 (14), 5400 (14), 5765 (14). Fraga CN 2094 (14), 2108 (14), 2428 (14). França F 4375 (10). França GS 226 (15). Freire R 100401 (15). Freire AG SP269674 (15). Freire AL 586 (14). Furlan A CFCR705 (10), SP259013 (10). Galvão MN R204502 (15). Garcia D 25 (5). Garcia RJF 597 (15). Gasper AL 2725 (2). Gavilanes ML 2315 (15). Gehrt A SP4126 (10). Giulietti AM CFCR2185 (10). Godoy Jr. UFOP6873 (14), UFOP6879 (14). Goes OC 133 (14), 310 (14), 641 (5), 857 (13), 1071 (15), RB49895 (15). Goldenberg R 484 (15), 1285 (14). Gomes 1204 (14). Gomes AA RBR6277 (15). Gomes JCJ 2042 (10), 3619 (15). Gomes JML 256 (15), 309 (14), 321 (15). Goodland R 3995 (10). Grandi TSM 85 (14), BHCB4173 (15), BHCB17408 (14). Groppo Jr.M 18 (15). Grotta AS SPF15107 (5), SP385033 (5). Grupo VIC8020 (15). Guimarães E 30 (14). Handro O SP50060 (15), SPF164922 (15). Harley RM 24963 (10). Hashimoto G 41 (15), 670 (5), 1292 (15), 1298 (14), 1300 (10), 1302 (15), 1303 (10), 1304 (15), 1308 (5), 1309 (1), 1362 (15), 1621 (15), 1748 (6), 1790 (10), 1849 (15), 3156 (15), 3168 (14), SPSF8168 (15), 8843 (15), 11628 (1). Hatschbach G 11408 (14), 23493 (10), 27837 (10), 28041 (9), 29885 (10), 31416 (14), 38006 (14), 41393 (14), 44717 (10), 46893 (14), 49959 (14), 55452 (15), 58014 (15), 61787 (1), 61872 (14), 64114 (1), 64117 (14), 64187 (10), 66280 (10), 67542 (10), 69013 (10), 69048 (14), 69170 (12), 69785 (10), 77591 (10). Hauff I 7 (15). Heiden G 942 (14). Hensold N CFCR3186 (10). Heringer EP 98 (15), 3953 (1), 7397 (1), 7597 (1), 11912 (4), 15022 (15), 22027 (10), 22208 (2), 5927A (10), RB93495 (1). Hermes W 5705 (2), 5874 (5). Hoehne FC 291 (15), SP4857 (9), SP4880 (14), SP4994 (14), 5229 (2), SP5692 (14), SP17418 (14), SP25069 (14), SP32199 (15), SPF164900 (2), SPF164903 (5). Hoehne W 5560 (14), 5705 (2), 5874 (2), SPF 15012 (10), SP44791 (14), SP385028 (15), SP385032 (14), SPF 10560 (15), SPF 12443 (5), SPF13291 (15), SPF14978 (15), SPF 14983 (15). Honda S PMSP1315 (15), 1510 (13). Ichaso CLF 32 (14). Irwin HS 2045 (15), 2149 (5), 19757 (14), 20403 (10), 20576 (2), 23123 (10), 23322 (14), 23827 (10), 25842 (10), 26078 (10), 26989 (10), 27235 (10), 27418 (10), 27530 (9), 28106 (14), 28614 (10), 28708 (14), 28858 (14). Jesus JA 2058 (15). Joly AB 1391 (10), 1404 (10), 2166 (11), 2549 (10), 2894 (10). Jouvin PP 212 (15), 227 (10). Junior AJF 121 (13). Junqueira AB 66 (15), 129 (15). Kallunki JA 330 (14). Kamino LHY 399 (14). Karine PAMG54413 (15). Kennedy H 871 (14). Kinoshita LS 302 (15). Kirizawa M 1221 (10), 1934 (33), 3301 (1). Klein VLG 1041 (14). Klitgaard BB 1173 (10). Koch I 32246 (14). Kollmann L 1023 (4), 1652 (8), 1723 (6), 5550 (2), 5970 (2), 7875 (4), 10454 (14), 11367 (15), 11367 (17), 11485 (8), 11666 (4). Kral R 75705 (15). Krieger PL 146 (14), 1555 (2), 7053 (15), 7067 (15), RBR8665 (15), 10147 (15), 10454 (2), 19130 (14), 19632 (2), 20291 (15), CESJ20297 (15), 20299 (14), 20972 (15), CESJ22302 (14), 22343 (15), CESJ23226 (14), 23301 (14), 23650 (14), 23651 (14), 24037 (14), SPF160756 (14). Kuhlmann M 2562 (13), 3196 (5), 3860 (6), SP385042 (15), 4120 (10). Kuhlmann R 100439 (5), R100506 (2). Kuhlmann JG 34 (1), 37 (1), 117 (1), 127 (10), 3541 (14), 6545 (5), 6606 (14), 6636 (14), 6723 (14), 6826 (14), 10454 (14), 10990 (14), RB20300 (13), RB72952 (14), R100435 (15), R100449 (15), R110498 (15), 100500 (15), HB111184 (16), RB 111186 (2), RB 137909 (1). Kuhlmann JY 83 (15), VIC1487 (13), VIC1498 (13), VIC2323 (1), VIC4861 (13). Kuhn E SP153851 (10). Labiak PH 4935 (14), 5092 (14). Labouriau L 1133 (10). Lage EA UFOP4250 (15). Lampaie A 37 (15). Lanna JP 230 (14). Lanze A 1720 (2), 1768 (2). Leane N 711 (15). Leise B 15069 (14). Leitão HF 28 (15). Leitão Filho HF 1914 (5), 2014 (10), 22894 (1). Leonello AC RB458260 (10). Leoni FS R180741 (14). Leoni LS 1938 (14), 2991 (4), 3252 (14), 3268 (14), R180742 (15). Lima HC 2578 (16), 5888 (13). Lima LR 28 (4), 48 (10), 256 (10), 366 (14). Lima S 13257 (14), 14207 (15), 14208 (14). Lindeman J 40 (14). Lisboa A RB4666 (13), LMPR 7 (15), 83 (15), 116 (15). Loefgren A 31452 (10) 31453 (10), 31456 (15). Lombardi JA 2538 (10), 2624 (15), 4676 (10), 5000 (14), 5842 (15). Lopes MA BHCB12780 (15). Lorenzi H 1369 (10). Lúcio K R200872 (15). Luederwaldt H SP13816 (14), SP13724 (15). Lutz A 496 (14), 753 (14), 812 (14). Lutz B 584 (14). Maas PJM 3267 (14), 3411 (14). Macedo A 608 (1), 1417 (1). Macedo EE 250 (1). Macedo JF 2608 (15), 2734 (15), 2772 (10), 2774 (15), 2927 (15), 3064 (15), 3250 (15), 3253 (15), 3273 (10), 3361 (10), 3604 (10), 3657 (15), 3728 (15), 3779 (15), 3976 (15), 4143 (15), 4144 (15), 4189 (15). Machado AFP SP445084 (15). Machado TM 283 (14). Magalhães M 2845 (14). Magnago LFS 1240 (14). Maia VCR R18504 (15), R199124 (15). Mamede MCH CFSC6893 (9), UEC48514 (9). Mansano VF 507 (15). Mantovani W 446 (10), 582 (10), 1361 (10), 1385 (10), 1681 (10). Marcondes FW 871 (1). Marinis G 354 (15), 498 (15). Marquete R 88 (16), 685 (14), 945 (14). Martinelli G 489 (14), 3171 (14), 8036 (14), 8697 (14), 9056 (14), 9220 (10), 9285 (14), 10372 (14), 10403 (6), 10681 (4), 10865 (4), 12016 (14), 13133 (14). Martins ER 38 (10), 40 (10). Martins JMO 12 (15). Martins LGS 178 (15). Mass PJM 3137 (2). Mautone L 42 (10), 508 (14), 581 (14). Mello Filho EL 546 (14). Mello-Silva R 2407 (10). Melo JCFJ 543 (1). Melo MRF 1096 (6). Melo PHA 349 (1). Mendes MS RB451483 (14), BHCB113234 (14). Mendes OT SP43934 (15), SP269145 (15). Mendes S 563 (10), 702 (1). Menegatto MFM UFOP12684 (15), UFOP12952 (15), UFOP12957 (15). Menegatto OFM UFOP22405 (15). Menezes I MBML 2498 (15), MBML 2499 (15), SP274812 (15). Menezes NL CFCR3282 (15), CFSC6392 (11). Messias MCTB 350 (14), UFOP 1701 (14), UFOP6363 (15), UFOP6395 (14). Mexia Y 4284 (14), 5230 (13), 5359 (14), 5394 (1). MGC 860 (10). Milanezi MA VIES 820 (14). Milhomens LC 33 (10). Milliken W 4109 (14). Monteiro H 439 (15), 889 (15), 892 (10), 1057 (15), 1533 (15), 2099 (15), 2328 (15), 2470 (14), 2750 (15), 3334 (15), 3347 (15), 3359 (15), 3567 (15), 3601 (15), 4213 (14), 4214 (15), RBR6248 (15), 6256 (15), 24700 (14). Monteiro MABM RB68463 (15). Moraes L R204503 (15). Moraes M 226 (15). Moreira AX 103 (14). Mota ALP 302 (1), 1077 (1), 2000 (13), 2125 (1). Mota RC 430 (14), 1939 (10), 2124 (9), 2139 (2), 2142 (14), 2292 (11), SP369149 (11). Nicolau SA 186 (14), 458 (1), 846 (1). Noronha 11 (15). Occhioni P 172 (16), 173 (16), 174 (14), 427 (15), 590 (16), RB44081 (14). Oliveira AES 273 (14), 255 (14). Oliveira DAL SP18530 (14). Oliveira F 63 (15). Oliveira JE 277 (1). Oliveira MC 92 (10). Pabst GFJ 5611 (14), 5707 (14), 6779 (14), 7303 (14), 8933 (15). Paciornik EF 126 (15). Palacios 2875 (14). Paolieri L SP41933 (15). Parajara RLG RBR28765 (15). Paschoal MES 2777 (10). Patzlaff R 82 (15). Paulo-Souza J 5970 (14). Pedralli G HXBH3508 (10), HXBH3516 (15), HXBH4216 (14), HXBH5172 (10), HXBH5173 (1), HXBH5174 (1), HXBH7202 (14), HXBH7203 (10), HXBH7204 (10), HXBH8169 (15), HXBH8170 (15). Pena FSR 2784 (14). Perches E SP293496 (15). Pereira AB 175 (14). Pereira BAS 2043 
(1), 2092 (1). Pereira E 723 (14), 1666 (10), 1770 (14), 1771 (14), 2111 (14), 2288 (2), 2511 (14), 3093 (14), 3981 (14), 4031 (15), 5752 (2), 7180 (14), 8877 (10), 9867 (14). Pereira M 996 (11), 1056 (11). Pereira OJ 453 (15), 1224 (15). Pereira SM BHCB3316 (15). Pereira-Silva G 6367 (14). Pickel DB SPSF360 (10), SPSF2835 (10). Pimentel AC SPF177387 (15). Pinto LJS 480 (14), 499 (34). Pio AD 91 (1). Pirani JR 167 (8), 230 (12), 3799 (1), 5645 (10), 5648 (10), 5801 (10), CFSC7961 (10), CFSC7972 (10), CFCR7979 (10), CFSC8044 (10), CFSC9223 (10), CFSC11965 (10), UEC 48512 (14), SP259146 (1). Platais GH 5 (14). Pompeu JB SP20933 (15). Porembski 2875 (14). Prado CA 10 (10). Prado J CFCR10491 (10). Prefeito SP1666 (15). Pregun MA 1 (15), 3 (15), 4 (15). Pscheidt AC 139 (15). Ramalho C RBR6249 (15). Rawitscher F 11511 (1). Regnell F R100343 (1). Rego SA 1310 (15). Reis VA BHCB51397 (15). Reitz 2643 (5). Rennó L BHCB629 (15). Rente EC 457 (15). Resende S BHCB64494 (15). Rezende SG 2310 (14). Riina R 1350 (10), 1360 (10). Rizzini 75 (14). Rodarte A 4Ad (15). Rodrigues RR 188 (6). Rollo MA 26 (1), 35 (1), SPF68229 (9). Rollo MAL SPF68231 (14). Romero R 5120 (10), 6662 (1), 6769 (1). Rosa M R52232 (14). Rossato SC 33814 (15). Rossi L 40 (13), 1047 (6), 1076 (10), 1143 (14), CFSC7005 (2), UEC 48508 (2). Roth L 1556 (14), 15578 (1). Rozza A 244 (1). Sakuragui CM CFCR15275 (10), ESA23501 (10). Salino A 4000 (14). Sampaio A 1415 (15), 1438 (15), 3058 (10), 3288 (10), 7391 (10), 7847 (15), 8578 (15), R100738 (15), R99349 (15), R99388 (15). Sampaio AJ 1553 (15), 4397 (15), 7391 (14), R99330 (15). Santos AA 1222 (1). Santos E 2053 (14), R99971 (15). Santos MCF 238 (14), 388 (14). Santos MG 667 (10). Santos N 233 (2). Sarmento S 19723 (15). Sasaki D 432 (10), 990 (9). Saturnino HM 115 (15), 902 (10), 1303 (10). Scatena VL CFCR10462 (10). Scavone O SP385027 (15). Schwacke P 4/916 (1), 7107 (2), 7985 (9), R98801 (1), R100504 (14). Semir J 673 (10), 2824 (10), 5028 (10). Serafim H 321 (13), 374 (13). Sevilha AC 4337 (10). Shepherd GJ 7005 (9), 7306 (10), 5775 (14). Silva AF 1257 (15). Silva AG 750 (14). Silva CC UFOP19363 (15). Silva DGR 242 (1). Silva IM 29 (14), 305 (15), 687 (15). Silva RCC 14 (14). Silveira A 40 (10), 490 (15). Silveira LT 22600 (10). Simonelli M 1567 (14). Soares JAP VIC26215 (15). Sobral M 11115 (10), 12567 (14), 13858 (14). Sobrinho FA 56 (15). Sofi JIL 2 (14). Somner GV 696 (15). Sousa ATA PAMG52973 (15). Souza A 129 (10), 241 (2), 322 (2), 542 (2), 1472 (14), 1975 (10), 1994 (10), R163337 (14), R175183 (14), R183164 (14), R203058 (2), R209342 (15). Souza TCR SP293583 (15). Souza VC PMSP908 (15), 1958 (15), 9064 (14), 10838 (10), 22066 (10), 23205 (14), 28304 (10), 32885 (14), 32902 (1). Stehmann JR 1408 (1), 3106 (14), 4150 (10), 4987 (14), BHCB18914 (10), BHCB27889 (1), MBM256254 (10). Stranghetti V 97 (1), 229 (1), 240 (1). Sucre D 1372 (15), 1454 (14), 1497 (15), 1555 (14), 1829 (15), 2059 (15), 2340 (15), 3418 (14), 4483 (13), 4577 (4), 4718 (16), 10696 (14), RB167479 (14). Sugiyama M 10 (10), 89 (10). Sylvestre L 142 (14). Tameirão Neto E 1574 (1), 2161 (1), 3303 (14), 1595 (10). Teodoro 335 (15). Thereza M SPF39965 (15), SPF176681 (15). Thomas WW 5965 (10), 6165 (2). Toledo JF SP53538 (15). Tomasetto F 177 (1). Torezan JM 522 (14). Torres RB 74 (1). Tozzi AMGA 94 (10). Ule E 3279 (14), R100339 (14), R100444 (15). Usteri AP SP13716 (5), SP13717 (10), SP13723 (5). Valente MC 25 (14). Valio IM 226 (10). Valle LS R185729 (15). Vasconcellos MB UEC 32117 (5). Vasconcelos MF 41 (14). Vattimo I RB176681 (15), RB176682 (15). Venâncio JR 2225 (1). Verardo SMS 25220 (14). Verissimo P 630 (15), 792 (15). Vervloet RR 3453 (4). Vianna C 59 (14). Vianna S 371 (14). Vianna SF 424 (14), 3077 (14). Vidal CV 184 (10), 364 (14). Vidal JR 104385 (10), R 107705 (15), R157986 (15). Vidal WN 3 (15), 107 (15), 572 (15). Viegas AP HRCB982 (15), SP43928 (10), SP49372 (14). Vieira CM 215 (13), 783 (14). Vieira HCW 850 (1), 1067 (1). Vieira MCW 1428 (1). Vieira MF 116 (9), 529 (14). Vimercat JM 252 (4). Vinha D SP398164 (15). Wasicky B SP1 19677 (15). Webster GL 25434 (14), Weinberg B 468 (7). Werneck MS 27 (15). Wilhomens LC 33 (14). Xavier L 548 (15). Xavier S 248 (15), 319 (15). Yamamoto K 00/64 (10). Zappi DC 731 (15), 1706 (10), 2142 (10). 